\title{
$\bullet$ \\ Effects of High and Low Concentration Formalin in Embalming of Cadavers
}

\section{IJCRR}

Section: Healthcare

Sci. Journal Impact

Factor: $6.1(2018)$

ICV: 90.90 (2018)

(c) (7) (3)

Copyright@IJCRR

\section{Sadeesh T1, Prabavathy G ${ }^{1}$, Ethiraj $\mathbf{R}^{2}$}

'Associate Professor, Department of Anatomy, Mahatma Gandhi Medical College \& Research Institute, Sri Balaji Vidyapeeth, Puducherry, India; 'Tutor, Department of Anatomy, Mahatma Gandhi Medical College \& Research Institute, Sri Balaji Vidyapeeth, Puducherry, India.

\section{ABSTRACT}

Background: We were using a low concentration of formalin(10\%) for the preservation of donated bodies. However, it gives a short lifetime of the specimen and they are more proven for fungus growth. We use high concentration formalin (30\%) to achieve prior purposes and to observe any changes in the human tissues. The present study aims to compare high and low concentration formalin effect on the body tissues and rate of fungal growth.

Methods: The donated bodies were embalmed with high and low concentration formalin in the right femoral artery. Then observation was made over the skin, muscle, nerves, vessels, and solid organs like liver, lung \& brain.

Results: In high concentration formalin the lifetime of the specimen was more but the quality and fungal growth were the same as low concentration formalin; the quality of the cadaver was poor compared to low concentration formalin.

Conclusion: The use of low concentration formalin results in good quality cadaver over the high concentration formalin.

Key Words: Cadaver preparation, Embalming, High concentration formalin

\section{INTRODUCTION}

Embalming is an art of mankind, artificially done to preserve the dead body. ${ }^{1}$ It is done by the composition of many chemicals to prevent the decomposition and purification of the dead one. ${ }^{2}$ The golden standard of studying anatomy is well established by Cadavers as a principal tool of anatomists for teaching gross anatomy. Dissection of cadavers will provide the learner to have an idea of the topography and texture architecture of the human body. At the same time, it improves the dissection and surgical skills of the students. So dissection plays a major role in medical education. To meet out the successful cadaveric dissection is fulfilled by the proper preparation and processing of the donated body. So that leaner will have the experience of near-normal ante mortem appearance of the body. An all Indiasurveyhas recommended a precise quantity of the preservatives used and colouring agents to be used for dissection purpose cadavers. ${ }^{3}$

The most historic book of medicine is an anatomical treatise, published in 1543, "De Humanicorporis fabric" is based on the dissection of the human corpus by An- dreas Vesalius. ${ }^{4}$ The embalming process with formalin was found a long time ago but it was not used till the $18^{\text {th }}$ century. ${ }^{5}$ Though the plastination was developed in 1973, which preserves cadaver by polymer and makes it hard. ${ }^{6,7}$ The aim of the present study is to compare high concentration formalin and low concentration formalin effect on the body tissues and rate of fungal growth.

\section{MATERIALS AND METHODS}

This study was carried out in the department of anatomy at Mahatma Gandhi Medical College \& Research Institute, Sri Balaji Vidyapeeth, Puducherry from 2016to2019. Thirtyfive voluntary donated bodies used for undergraduate and postgraduate cadaveric teaching were used for this study. The cadavers were divided into two groups.

Group I: 20 - Cadavers were embalmed with $10 \%$ formalin (100 $\mathrm{ml}$ of $37 \%$ formaldehyde per litre of water)which was used as low concentration formalin(LCF). ${ }^{5}$

\section{Corresponding Author:}

Sadeesh T, Associate Professor, Department of Anatomy, Mahatma Gandhi Medical College \& Research Institute, Sri Balaji Vidyapeeth Puducherry, India; Phone: 9443287343; E-mail: dr81870@gmail.com.

ISSN: 2231-2196 (Print)

Received: 16.09 .2020
ISSN: 0975-5241 (Online)

Revised: 02.09 .2020
Accepted: 10.10 .2020 
Group II: 15-Cadavers were embalmed with 30\% formalin $(300 \mathrm{ml}$ of $37 \%$ formaldehyde per litre of water)which was used as high concentration formalin(HCF)(Table 1). ${ }^{8,9}$

The donated bodies were cleaned with running water and antiseptic soap. The hair was removed by shaving and then thoroughly washed again.

Then the body is kept in the embalming stage. The incision is made on the right femoral triangle to expose the femoral sheath and to explore the femoral artery. After identifying the femoral artery, the sheath around it was cleared. A transverse incision was made in the anterior wall of the artery and the cannula was introduced into it. Then the embalming mixture was injected in the femoral artery at 15 psi by an embalming fluid injector. After injecting about 10 to 12 litres, the reversal of embalming fluid is done towards the foot on the same limb. The embalmed cadavers were kept on the embalming stage for $24 \mathrm{hrs}$. The cadavers were examined for the proper embalming and shifted to the storage tank until utilized for the dissection. The changes in skin, muscle, nerves, vessels, and various organs were observed in both groups and tabulated. The significant difference between the groups was statistically analyzed using non-parametric, Fischer exact test. The p-value $<0.05$ was considered statistically significant.

\section{OBSERVATIONS \& RESULTS}

The following observations were made in the two groups studied(Table II). Out of 20 cadavers embalmed using low concentration formalin in Group I, a significant colour change over the skin was observed in 2 cadavers $(10 \%)$. The skin was dark, hard and we felt difficulty in separating it from the underlying subcutaneous layer in 10 cadavers (66.7\%) embalmed using high concentration formalin in Group II. Whereas in the remaining 5 obese cadavers (33.3\%)the skin changes were minimal, may due to its fattier disposition in their subcutaneous layer.

In all cadavers of Group I, the muscles noted were soft and ease to retraction and mobilization. But in Group II12(80\%) cadavers the muscle became hard while retracting it sooner gets torn. At the same time if it was exposed outside for a few hours it became dark and lose its consistency.

While looking into nerves and vessels, there was a clear distinct appearance of those structures in case of Group I. Whereas in Group II, 13 cadavers (86.7\%) showed changes in nerves, and 12 cadavers (80\%) showed changes in vessels. The vessels and nerves were very thin and brittle. Sooner gets dried off and difficult to differentiate from both the structure.

All the organs from the cavity of the cadavers were observed. Liver from 13 cadavers (86.7\%), lung from 13 cadavers
(86.7\%) and brain from 14 cadavers $(93.3 \%)$ of the Group II was felt hard and showed shrinkage. In the case of brain specimens, the cortex became dark after exposure to the atmosphere for a few hours.

In both groups, fungal growth was observed when the cadavers or specimens were kept outside for a long time, which is more prevalent in Group I.

\section{DISCUSSION}

The preservation of cadavers in low concentration embalming is effective than high concentration. On reviewing the literature, the high concentration embalming reports that the quality of cadaver is not good for dissection. To our knowledge, there was no reported evidence of it. So we attempt to study the effect of high concentration formalin in the present study.

A study report revealed that light colouration was observed in Group I than Group II..$^{5,10}$ In the present study, the skin of Group IIwasdark and very tuff in about $66.7 \%$. In the remaining $33.3 \%$ of Group II, the skin was not tuff to dissect, because those cadavers were moderately obese.

Kalanjati VP et al ${ }^{10}$ reported that the vessels were intact in Group I (Fig.1A). In the present study, the vessels were intact in both groups. In due course of dissection, the vessels of Group II cadavers became collapsed which sooner became cord-like and difficult to differentiate from nerves (Fig.1B).

The high ratio of formalin with low methylated spirit is not a concern of mould. Thus the high water content of tap water would have resulted in the mould. ${ }^{3}$ Andlow formalin embalming with result in no growth of mould. ${ }^{6}$ In our study, we also observed the growth of mould in both the groups, stating that there was no significant role in the concentration of formalin in the prevention of the mould (Table II).

The formalin is a good fixative as indicated by its effects in looking into both high and low concentration formalin embalmed cadavers. The use of high concentration formalin showed that the muscles' softness and the colour were lost, later it became hard and brittle. It results in the loss of flexibility of the specimen.

The solid organs like the liver, lung, and brain showed that high concentration made the organ to shrink and became hard (Fig.1C to H). This may be because of the chemical reaction between the formalin and protein. At the same time, the cortex of the brain became dark.

\section{CONCLUSION}

It is concluded that high concentration formalin is not an effective option for the embalming of cadavers. Its effect on 
cadaver during dissection was not advantageous and fails to prevent fungal growth. Furthermore, the factor for the fungal growth may be due to the use of tap water during the embalming. This information will help us in updating the existing knowledge.

\section{ACKNOWLEDGEMENT}

The author is grateful to the staff of the Department of Anatomy, Mahatma Gandhi Medical College \& Research Institute, Pondicherry. I express my gratitude to Dr. ArunShanmugam, Assistant Professor, Community Medicine, Mahatma Gandhi Medical College \& Research Institute, Pondicherryfor his timely help in statistical analysis.

Conflict of interest: Authordeclares there is no conflict interest.

Source of Funding: There is no source of funding.

\section{REFERENCES}

1. Ajmani ML Embalming: Principle and legal aspects 1st ed. New Delhi: jaypee brothers medical publishers; 1998.

2. Frederick LG. and Strub CU. The Principles and Practice of Embalming. 5 ed. Professional Training School. India. 1989.

3. Mysorekar VR., Zargar R.K. and Hasbans Singh. Embalming and preservation of cadavers: An all India survey. J. Anat Soc. India 1977; 26(3): 149- 55.

4. Rath G, Garg K. Inception of cadaver dissection and its relevance in the present day scenario of medical education. J Indian Med Assoc. 2006;104(6):331-3.

5. O'Sullivan E, Mitchell BS. An improved composition for embalming fluid to preserve cadavers for anatomy teaching in the United Kingdom. J Anat (Internet). 1993;182 (2):295-7.

6. Saeed M, Rufai AA, Elsayed SE. Mummification to plastination. Saudi Med J. 2001;22(11):956-9.

7. Moore CM, Brown CM. Gunther von Hagens and Body Worlds Part 1: the anatomist as prosektor and proplastiker. Anat Rec B New Anat. 2004;276(1):8-14.

8. Natekar PE, Desouza FM. A new embalming fluid for preserving cadavers. J Krishna Inst Med Sci Univ. 2012;1(2):76-80.

9. Natekar PE, Souza FM De. Eosin as coloring agent for embalming of cadavers. Natl J Basic Med Sci. 2011;1(4):4-5.

10. Kalanjati VP, Prasetiowati L, Alimsardjono H. The use of lower formalin-containing embalming solution for anatomy cadaver preparation. Med J Indones. 2012;21(4):203-7.

Table 1: Composition of embalming fluids Low and High concentration formalin

\begin{tabular}{lcc} 
Component & LCF & HCF \\
Formaldehyde & $100 \mathrm{ml} / \mathrm{l}$ & $300 \mathrm{ml} / \mathrm{l}$ \\
Methylated Spirit & $500 \mathrm{ml} / 1$ & $500 \mathrm{ml} / 1$ \\
Phenol & $100 \mathrm{l} / \mathrm{l}$ & $100 \mathrm{~g} / \mathrm{l}$ \\
Glycerol & $500 \mathrm{ml} / 1$ & $500 \mathrm{ml} / \mathrm{l}$ \\
Thymol & $100 \mathrm{mg} / 1$ & $100 \mathrm{mg} / \mathrm{l}$ \\
Eosin & $25 \mathrm{ml}$ & $25 \mathrm{ml}$ \\
\hline
\end{tabular}

LCF- Low Concentration Formalin, HCF-High Concentration Formalin

Table 2: Distribution of changes in percentages of various tissues of both the groups

\begin{tabular}{|c|c|c|c|c|c|c|c|c|}
\hline Details & Skin & Muscle & Nerve & Vessels & Liver & Lung & Brain & Mould \\
\hline $\begin{array}{l}\text { Group I } \\
(20)\end{array}$ & $2(10 \%)$ & o $(0 \%)$ & $3(15 \%)$ & $1(5 \%)$ & o $(0 \%)$ & o $(0 \%)$ & $4(20 \%)$ & $13(65 \%)$ \\
\hline $\begin{array}{l}\text { Group II } \\
(15)\end{array}$ & $10(66.7 \%)$ & $12(80 \%)$ & $13(86.7 \%)$ & $12(80 \%)$ & $13(86.7 \%)$ & $13(86.7 \%)$ & $14(93.3 \%)$ & $10(66.7 \%)$ \\
\hline p-value & ${ }^{*}$ o.ool & ${ }^{*}$ o.ool & ${ }^{*}$ o.oo1 & ${ }^{*}$ o.ool & ${ }^{*}$ o.ool & ${ }^{*}$ o.oo1 & ${ }^{*} \mathrm{o} .001$ & 0.9181 \\
\hline
\end{tabular}

${ }^{*} \mathrm{p}$-value $<0.05$ - significant 


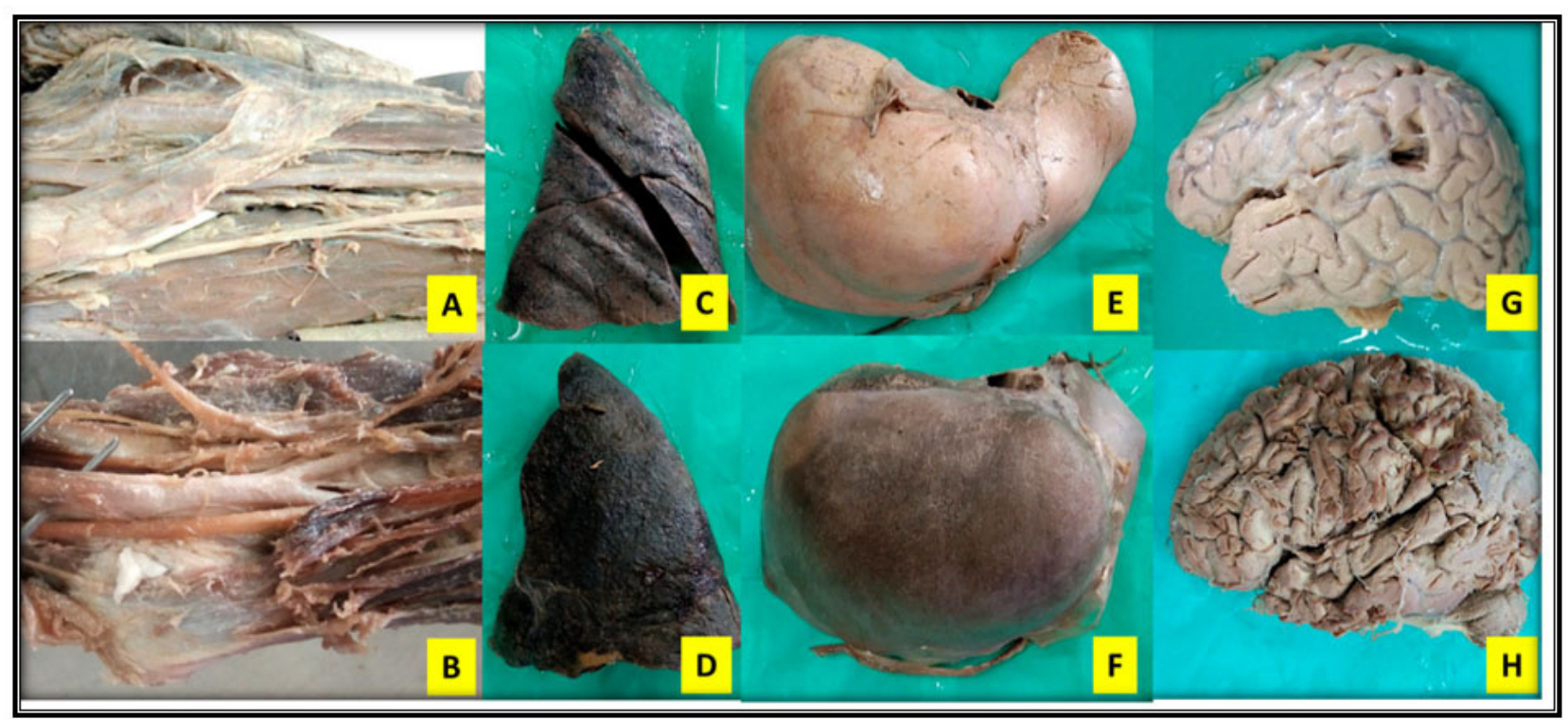

Figure 1: A) Photography of right cubital fossa showing muscular boundaries with distinctly visible artery and nerve using LCF B)Photography of right cubital fossa showing muscles that are dark with dried neurovascular bundlesusing HCF.C) Lung -Normal contour using LCF. D) Lung with shrinkage using HCF, E) Liver - Normal contour using LCF. F) Liver -dark with shrinkage using HCF, G) Brain using LCF, H) Brain- dark and shrunkenusing HCF. 